\title{
CENA DE NARRAÇÃO E A CENA EM TESTEMUNHO
}

\author{
Abílio PACHECO \\ Universidade Federal do Pará (UFPA) \\ apacheco@ufpa.br
}

Resumo: Em muitas narrativas tradicionais em primeira pessoa, especialmente romances, é constituído um cenário para o desenvolvimento da narração, cenário em que muitas vezes há interação entre o narrador e o narratário (seja este leitor, ouvinte, destinatário de cartas...) mas cujos elementos do tempo presente anulam-se, apagam-se, dando lugar ao passado, ao tempo da narrativa. Nestas narrativas, assinaladas sob o mesmo nome próprio narrador e personagem apresentam-se distanciadas no tempo e na arquitetura do texto. Em narrativas de testemunho, situadas na cisão entre ficção e realidade, e nas quais a fragmentação se dá - entre outras coisas - pela fusão dos tempos e desarticulação causal, justapondo e comprimindo-se narrativa e narração. A constituição desta cena cerca-se de uma problemática decorrente da compressão cronológica e de certa anulação da distância entre narrador (-autor) $e$ personagem. Em tais narrativas, ao mesmo tempo assume uma supra-cena no tribunal da História e outra perspectiva na relação do narrador com a experiência e consigo mesmo.

Palavras-chave: Narrativa. Cena. Narração. Testemunho.
Resumen: En muchos relatos tradicionales en la primera persona, especialmente novelas, es el escenario para el desarrollo de la historia, escenario en el que a menudo existe interacción entre el narrador y el lector (si este lector, oyente, receptor de letras ...) pero cuya esta vez los elementos se anulan, se apaga, dando paso al pasado, el tiempo narrativo. En estos relatos, marcado con el mismo narrador mismo nombre y el carácter se presentan distanciado en el tiempo y la arquitectura texto. En los relatos de los testigos, que se encuentra en la división entre la ficción y la realidad, y en el que se produce la fragmentación - entre otras cosas - la fusión de tiempo y desarticulación de causalidad, yuxtaponiendo y comprimiendo la narrativa y la narración. La constitución de esta valla es una escena problemática debido a la compresión cronológica y en la cancelación de la distancia entre el narrador (-author) y el carácter. En estos relatos, al mismo tiempo que se tarda en un supra-escena en el tribunal de la historia y otra perspectiva en la relación del narrador con la experiencia y con él mismo.

Palabras clave: Narrativa. Escena. Narración. Testimonio. 
0.

Fiat Lux! E o mundo passou a existir. Não é assim!? "Há muitos e muitos anos...”, “Era uma vez...”, "Meu compadre me disse...", "Quanto eu estava caminhando para cá...” e muitas outras possilidades de lançar o laço linguístico e enlaçar-se o leitor na trama. Nossa competência narrativa de imediato sabe qual o tipo de texto teremos pela frente. Claro, nem sempre é tão óbvio assim. Ou nem sempre esta capacidade quase inata de perceber perdura conforme a gente prossiga no processo de escolarização. Fiat lux! E as crianças apagam as luzes e acendem uma lanterna embaixo do lençol para contarem histórias de terror. Ainda com a competência narrativa inata intacta, elas reproduzem um cenário para a criação das histórias. O narrador é aquele que fica com a lanterna em mãos, quem determina o ritmo do enredo, dá o tom para as vozes dos fantasmas que assustam e o tom das vítimas assustadas. Existem narradores que performam, crispam as mãos como garras, simulam saltar sobre os ouvintes. Tão naturalmente, como deixasse-os guiar por um script. O entorno à lanterna para a contação de história equivale à cena narrativa por excelência: a contação diante da lareira (como o lemos em Walter Benjamim - Experiência e Pobreza) ou a roda em torno da fogueira onde griôs africanos ainda hoje devem narrar. A roda em torno do fogo hoje substituída por outros processos narrativos como o escurinho do cinema, onde ficamos de olhos vidrados no ecrã.

A despeito de haver este cenário arquetípico para o ato de narrar, todos nós certamente temos o nosso cenário ligado à nossa história pessoal. Ainda hoje ouço, na calçada da Travessa da Mangueira 101 em Coroatá, meu avô após a sesta do almoço esticar-se numa cadeira de macarrão, à sua frente um tamborete com assento de couro, onde ressona um gato mouriço. Meu avô, ora encostava-se na cadeira de macarrão ora cofiava o dorso do gato, e, sem pressa alguma, escorria uma narração a fio: algum episódio familiar, 
alguma façanha de um vizinho, alguma busca por preso fugido. Nenhuma fogueira há nesta minha cena de narração, assim como talvez não haja nas cenas de narração que vocês certamente estão tentando resgatar na memória. Certo, porém, é que esta cena existe e ela é fundamental.

No fecundo ensaio de Walter Benjamim sobre o narrador, o camponês sedentário e o marinheiro comerciante não seriam apenas dois modelos tradicionais/arquetípicos de narradores, mas também dois modelos de instauração de cenas arquetípicas de narração. A atenção curiosa aos recém chegados e audiência respeitosa aos autóctones constituiriam a raiz destas cenas. Ao porto de chegada e à cabana de morada, une-se a imagem da oficina onde os mestres artífices, antigos aprendizes migrantes agora camponeses sedentários, aperfeiçoam a arte de narrar (1994) Os narradores em primeira pessoa, mesmo em romances, demonstram muitas vezes a necessidade de instaurar uma cena de narração. Eles, de algum modo, remontam e retomam procedimentos próprios dos modos primitivos de narrar. Eles, afirma Walter Benjamin, “gostam de começar sua história com uma descrição das circunstâncias em que foram informados dos fatos que vão contar a seguir, a menos que prefiram atribuir essa história a uma experiência autobiográfica”. (1994, p. 205)

Podemos observar que a constituição da cena de narração remonta a textos fundadores da literatura ocidental, como em Sófocles e Homero. Diante do palácio de Édipo, da chegada dos suplicantes pela manhã até sua expulsão ao entardecer, a história transcorre em um mosaico de narradores uma cena múltipla de narração, através da qual é reconstituída, pelos moradores de Tebas, pelos espectadores gregos e por nós leitores hodiernos, a vida do desafortunado rei. Em outro texto fundador da literatura ocidental, "a longa narração de suas aventuras [de Ulisses] (Cantos IX, X, XI e XII)”, ao rei Alcino, "o que nós, muitas vezes, conhecemos como Odisseia", que se constitui como uma cena de narração na qual podemos notar "uma reflexão do poeta sobre a importância do canto 
poético" (GAGNEBIN, 1006, p. 26), o que revela não só “uma autorreflexão poética ou poetológica da parte do autor da Odisseia", mas também notamos "por meio da narração e da autonarração em particular, uma auto-constituição do sujeito" (p. 37).

Esses dois textos fundadores parecem-nos indicar também as cenas narrativas literárias arquetípicas da poética ocidental. A constituição dessas cenas de narração coadunam com os perfis dos heróis. Ao íntegro e ileso herói da epopéia (cujo desfecho corresponde a recepção em seu reino), a narração desfia-se com mais integridade. Ao gauche e lesado Édipo (ao final da primeira das peças: automutilado, expulso e exilado) a narração esboroa-se de modo mais fragmentado.

1.

De Ulisses e Édipo até nós, muito há de novo (novidade), e muito há de novo (novamente). A progressão temporal das narrativas em primeira pessoa corresponde uma progressão ascendente ao individualismo, ao egocentrismo. Cada vez mais estamos diante de narrativas e de gêneros narrativos intimistas, memorialistas, autobiográficos, testemunhais, narcísicos, bildungsromane, metaficcionais, em forma de diários íntimos, etc. Progressão que também podemos notar nas artes da imagem: o autorretrato não era apenas um exercício difícil de técnica para a pintura numa época que começava a dispensar modelos vivos. Era uma evasão para um 'eu' desejoso de exposição pública, desejoso de evasão de privacidade, bem como um gesto de demonstração da autonomia do sujeito. Se nas artes plásticas esta progressão para o 'eu' extravagante e autônomo pode não ter evoluído de modo tão pulverizante quanto nos romances, o mesmo não podemos dizer da fotografia, enquanto uso vulgar e corrente não necessariamente circunscrita ao território artístico. Em outras palavras: Self-se quem quiser. Um dos maiores indícios do estado atual de individualismo e autonomia do sujeito (o que nos possibilita uma reflexão anacrônica sobre outras formas de manifestação do individualismo) são os auto-retratos a partir das 
câmeras de celular. O Selfie possibilita ao usuário fotografar a si mesmo sozinho ou ao lado de amigos anônimos ou próximo a pessoa ilustres (raramente ao lado de objetos) dispensando totalmente a ajuda de quem quer que seja à distância apenas do próprio braço. A proximidade "especular" da objetiva associada ao desejo do sujeito de aparecer pouco possibilitam uma imagem aberta, ampla, panorâmica, dificilmente capturando algo do entorno ou capturando apenas um objeto específico, mas secundário e selecionado; nos Selfies raramente registra-se acidentalmente algo de um entorno cultural e de delimitação temporal. Selfie tem muito de imagem, um pouco talvez de cena, mas quase nenhum cenário ${ }^{1}$. Este modo de se retratar, à medida que corresponde ao ápice da individualização, sinaliza o apagamento quase total do cenário. O Selfie corresponde a um marco significativo na história do individualismo e de autonomia do sujeito, mas também de evasão da privacidade e das formas de exposição pública, pois as imagens logo ganham as redes sociais. Todos nós sabemos exemplos de Selfies que imediatamente ganharam notoriedade e rapidamente sucumbiram ao anonimato. Isto, entretanto, não vem ao caso para esta comunicação.

Ulisses e Édipo não cabem numa Selfie. Nem juntos, nem sozinhos. Embora suas narrativas remetam a uma centralização com personagens protagonistas, elas pouco têm de individualização do sujeito, posto que eles se apresentam um representativo de uma nação e o outro um mito de exemplaridade. A visão ampla de mundo na Grécia de então não possibilita o estreitamento do foco e a anulação do cenário do relato. Os entornos sociais e culturais de suas cenas de narração são essenciais. A leitura dos cantos IX a XII da Odisséia nos coloca na corte do rei Alcino e a leitura (ou assistência à exibição) de Édipo Rei nos

\footnotetext{
${ }^{1}$ Quando este texto foi escrito, ainda não se havia popularizado o extensor para celulares, vulgarmente chamado de "pau de selfie". Optei por manter as reflexões como estão originalmente. Tanto pelo fato de não julgar a atualização necessária para o corpo do trabalho atual, quanto por que as afirmações gerais feitas sobre o selfie em muito valem para os selfie com o novo acessório.
} 
coloca em frente ao palácio do rei Édipo em Atenas ${ }^{2}$. À leitura estamos próximos ao lugar, metaforicamente ou discursivamente. Ao texto de Sófocles cabe uma ressalva para não comprometermos o método de nossa exposição. O fato de Édipo Rei pertencer ao gênero dramático e ter sido escrito como uma peça para exibição pública constitui-se necessariamente para uma presentificação, o que corresponde a um tipo específico de cena de narração não circunscrito ao objeto de minha pesquisa nem a este trabalho. A saber: a cena de narração em textos dramáticos, televisivos e cinematográficos. Esta espacialização construída para o relato não é, entretanto, exclusividade das narrativas em primeira pessoa. Apenas a título de exemplo, observem que as parábolas de Cristo e os contos de Sherazade não abdicam da cena ou cenário: as montanhas e a alcova do sultão, respectivamente.

Dominique Maingueneau (1997), ao escrever sobre a cena enunciativa e contextualizá-la conforme a Pragmática, afirma que nos atos de fala, "a tomada da palavra constitui um ato virtualmente violento" (p. 31) regido por um contrato de fala, em que os papéis obedecem um conjunto de regras, de modo que o ato de linguagem é compreensível ao se inscrever nos registros jurídicos, do teatro e no domínio do jogo. Maingueneau, entretanto, destaca os riscos da concepção pragmática, que - tendo como prisma a Análise do Discurso - favorece a um certo apagamento da relação com o real da história, com a constituição de um fato discursivo e "com os efeitos de conjuntura em uma formação social determinada" (p. 32). Ao termos em mente as formações discursivas, torna-se importante “determinar qual é a posição que pode e deve ocupar cada indivíduo para dela ser o sujeito" (FOUCAULT, 1986, p. 109). Sujeito que se constitui em sujeito do discurso ao mesmo

\footnotetext{
${ }^{2}$ Uso o verbo colocar em sentido etimológico de locus = lugar, co = próximo. 
tempo em que se torna sujeito no discurso (MAINGUENEAU, 1997, p. 33). Eu sou neste ato enunciativo o que este enunciado e esta enunciação me possibilitam ser. Ao mesmo tempo que autor a constituo, ela me constitui como persona. Dela sou autor/(narrador) e personagem.

Neste mesmo trabalho, Mainguenaeu procura distinguir algumas deixis discursivas: o locutor e o destinatário discursivos, a cronografia e a topografia, bem como a cenografia. Segundo ele, uma deixis discursiva, que possibilita o acesso à cenografia de uma formação discursiva, existe porque

uma formação discursiva não enuncia a partir de um sujeito, de uma conjuntura histórica e de um espaço objetivamente determináveis do exterior, mas por atribuir-se a cena que sua enunciação ao mesmo tempo produz e pressupõe para se legitimar. (1997, p. 42)

Há de se distiguir ainda a existência de uma locução fundadora, uma cronografia e uma topografia fundadoras que auxiliam na constituição e na legitimidade de outras deixis (locuções, cronografias e topografias).

Num trabalho específico sobre o Discurso Literário, Mainguenaeu destaca a importância da cenografia para a narrativa, pois é através dela que o leitor tem acesso a cena englobante (que permite identificar um tipo ou gênero de discurso) e a cena genérica (que determina as condições de enunciação). Assim, "a história pode ser contada de múltiplas maneiras: pode ser um marujo contando suas aventuras a um estrangeiro, um viajante que narra numa carta a um amigo algum episódio por que acaba de passar" (essas artimanhas são demais conhecidas nossas)... Acrescenta ainda a existência da "cenografia do diário íntimo, do relato de viagem, da conversa ao pé da fogueira, da correspondência epistolar etc" (p. 252). Ao leitor a narrativa chega primeiramente a partir dessa cenografia, que é "ao mesmo tempo origem do discurso e aquilo que engendra esse mesmo discurso" (p. 253) de modo a legitimá-lo e validar os estatutos do enunciador e do co-enunciador, do 
espaço (topografia) e do tempo (cronografia). Muitos textos literários, entretanto, apresentam uma cenografia autárquica cuja ruptura entre enunciado e enunciação sugerem um "puro alhures espacial e temporal". "Abolindo qualquer vestígio de situação de enunciação", “como se a página constituísse sua única cenografia” (p. 254).

A literatura do século XIX e boa parte do século XX, sobretudo as narrativas romanescas, são fartas na utilização da cenografia. No Brasil, não é difícil destacar a existência dela em: Dom Casmurro de Machado de Assis, narrado diante das imagens da casa construída semelhante a casa da infância. São Bernardo, de Graciliano Ramos. Grande Sertão Veredas de Guimarães Rosa em que "Riobaldo narra suas memórias a um paciente senhor [sendo] o romance o teatro de suas memórias e o fio que mantém toda a tensão da trama é o relacionamento amoroso e posto como condenável entre ele e Diadorim” (Seligmann-Silva, 2009, p. 133). Dois Irmãos de Milton Haltoum, cujo cenário de escritura é o antigo quarto dos fundos da casa dos dois irmãos (Omar e Yakub) e que no momento da narração é "herança" do narrador Nael nos fundos do Hotel Rochiram que tomou o lugar do antigo casarão.

Estas considerações sobre a cenografia literária nos ajudarão, mesmo que parcialmente, em algumas reflexões sobre a cena de escritura em narrativas de resistência / testemunho. Antes um breve incurso por estes conceitos.

3.

A principal referência ao tema da resistência é artigo, já clássico, do Professor Alfredo Bosi, "Narrativa e Resistência", capítulo do livro Literatura e Resistência (2002). São já recorrentes as leituras do capítulo citado, especialmente no que se refere às duas principais formas de resistência indicadas por Bosi em seu trabalho. A saber: a resistência 
como tema e a resistência como processo inerente à escrita (p. 120). Vou procurar um outro caminho. Indicar a aproximação ou intersecção dos conceitos de resistência e testemunho.

Ao explicar a resistência como tema, Bosi contextualiza o termo na década de 30 a 50 do século XX vinculando-o à participação ou ao engajamento de intelectuais contrários "ao facismo, ao nazismo e às suas formas aparentadas, o franquismo e o salazarismo" (p. 125). E destaca a publicação de Se questo è um uomo, de Primo Levi, como "um perfeito exemplo do clima ético" da época. Isto é um homem?, nas palavras de Bosi, testemunha a experiência de judeu de Primo Levi "lançado em um campo de concentração" (p. 126). Ao referir-se ao contexto brasileiro, cita As memórias do cárcere de Graciliano Ramos, afirmando-a "nem ficcional, nem documental, mas testemunhal". Bosi, em trabalho anterior, já havia se debruçado no caráter ficional das memórias do romancista alagoano, num texto de 1995, no qual apresenta logo no início que os jurados do prêmio do concurso latino-americano de romances, patrocinado pela revista cubana Casa de las Américas, “adotaram a expressão literatura de testemunho para qualificar um tipo de escrita [...] situada na intersecção de memórias e engajamento". E destaca: "Nem pura fícção, nem pura historiografia; testemunho" (1995, p. 309). Ao plasmar a dimensão ética contra os regimes totalitários e autoritários e colocar-se como voz de uma resistência (em alguma medida participante), de uma força que procurar firmar-se num ponto (físico ou ideológico) ou que se opõe a uma outra que lhe é contrária, essas narrativas possibilitam perscrutar os rastros de uma história que escapa às versões oficiais e testificam, revelam umas (muitas umas) outras Histórias.

Para o professor Seligmann-Silva (2003) é importante notar que "a literatura de testemunho é mais do que um gênero: é uma face da literatura que vem à tona na nossa época de catástrofes e faz com que toda a história da literatura [...] seja revista a partir do questionamento da sua relação e do seu compromisso com o "real'" (p. 373). Também aqui 
é importante entender a representação do testemunho situada na bifurcação entre o ficcional e o real. A escrita do testemunho demanda outras posturas interpretativas além do tradicional entendimento da literatura como estritamente ficcional, como puro fingimento. O poeta, agora, chega a sentir a dor que deveras sentiu, mas também se revela imbuído de um compromisso com a realidade histórica.

O testemunho é gesto individual de participação coletiva numa política de memória. Embora possam diferir quanto ao evento a ser testemunhado, suas características, ou mesmo da pessoa que testemunha, tanto na tradição alemã do Zeugnis, quanto na chave latino-americana do testemonio, ele "cumpre um papel de verdade histórica", como destaca o professor Márcio Seligmann-Silva, e o narrador (seja superstes, testemunha sobrevivente, seja testis, a testemunha como um terceiro) assume uma postura ética diante do tribunal da História. O compromisso de narrar a experiência traumática com vistas a a contribuir para que a memória sobre a catástrofe perdure e, quiçá, favoreça a não repetição do/s evento/s.

Neste sentido, o testemunho também se inscreve na tensão eu/mundo própria da resistência imanente à escrita, conforme a leitura que fazemos do texto do professor Alfredo Bosi. Segundo este, “a escrita de resistência, a narrativa atravessada pela tensão crítica, mostra, sem retórica nem alarde ideológico” o 'avesso' da normalidade da vida cotidiana do sujeito mediano. As matrizes deste pensamento estão na Sociologia do Romance de Lukács e Lucien Goldman. Se no romance nascente até início do século XX tínhamos o sujeito problemático numa sociedade degradada em busca de valores autênticos passamos gradativamente a ter um sujeito problemático por causa de uma sociedade degradada certo de que não existem mais valores autênticos. É preciso pensar este indivíduo não apenas sob a chave das identidades culturais, mas também em virtude da experiência das catástrofes, dos regimes totalitários e autoritários. A resistência se faz, então, utopia prospectiva num contexto distópico. Com ela busca-se o que Ítalo Calvino 
indicou na página final de As cidades invisíveis: achar no "inferno no qual vivemos todos os dias [...] o que não é inferno, e preservá-lo, e abrir espaço” (1990, p. 71).

A resistência imanente à escrita também se refere aos procedimentos e técnicas narrativos. Corresponde, conforme Bosi (p. 134), a "um movimento interno ao foco narrativo, uma luz que ilumina o nó inextricável que ata o sujeito ao seu contexto existencial e histórico". Ela tanto denúncia a desordem social como é fruto dela. Como demonstra Lizandro Calegari (2008) em sua tese de Doutoramento, os procedimentos estilístico-composicionais dos romances por ele estudados tanto servem como crítica à sociedade do Brasil sob o regime militar, quanto são reflexos da conjuntura instaurada pelo mesmo regime. A tortura, "o aniquilamento do sujeito e a desintegração da consciência do narrador" entre outras coisas, se refletem na fragmentação formal das narrativas cujos espectros são por si testemunhos (p. 295). O corpo fragmentado do romance, estranho à leitura acostumada à linearidade narrativa, corresponde em maior ou menor medida à desordem social no Brasil de então. O romance é ele mesmo, fragmentado, derruído e quase irreconhecível um elemento de resistência e força testemunhal.

Esta força pode ser percebida também pela composição do narrador no romance contemporâneo. O declínio da arte de narrar apontado por Walter Benjamim como algo constante cronologicamente associado aos modelos de progressos subjacentes às sociedades capitalistas e industriais pode ser lido também no texto de Adorno sobre a posição do narrador no romance contemporâneo (2003). O silêncio do narrador pós-II guerra, pósditaduras, pós-catástrofes, bem como a desintegração da narrativa, frutos de uma narração que rompe o silêncio pós-limite, deve-se ao próprio paradoxo da posição do narrador e, por extensão, do próprio autor: "não se pode mais narrar, embora a forma do romance exija narração" (p. 55). Adorno destaca a impossibilidade de narrar experiências vinculadas à violência e ao trauma. $\mathrm{O}$ romance contemporâneo não mais procura um compromisso com 
a representação (realista) da realidade, a organização linear, a certeza, a integralidade, ou com "a tentativa de decifrar o enigma da vida exterior" (p. 58). Ele se apresenta como linguagem, inscrevendo-se visivelmente como ilusão do real, mesmo ao se esforçar por captar a essência da vida exterior. Além disso, a distância estética entre o narrador e o leitor, antes fixa, agora é variável e o romance contemporâneo reconhece-se incapaz de dar conta de representar uma realidade desmensurada.

O narrador do romance contemporâneo assume a narrativa como construção, linguagem, e assume-se como mediador de uma realidade parcial, filtrada por sua visão, sua experiência, mas ao mesmo tempo procura possibilitar ao leitor caminhos para que este especule outras verdades. De diferentes modos e por diferentes motivos, o narrador tradicional, o clássico (Ulisses ou mesmo Édipo) e o contemporâneo esforçam-se por não desaparecerem da cena. Antes mostram-se. O narrador em primeira pessoa é um esforço de preservação e constituição da imagem humana. Por isto, em muitos desses romances é possível vislumbrar o espectro do autor sombreando o texto, e no caso das narrativas póstrauma, pós-catástrofe, ao assumir um compromisso com a verdade histórica esta sombra é essencial para uma reflexão política e humana que com um pouco mais de dificuldade consegue uma narrativa em terceira pessoa. Este narrador, em tempos de experiência em declínio, parece-nos estar muito mais perto da imagem performática, desinteiriça e manqueante do triste rei Tebas que do modelo épico de Ulisses (com a devida ressalva já feita).

4.

Acresce em narrativas sobre a ditadura militar no Brasil, e suspeitamos que em outros país onde houve ditadura no século XX, especialmente nos países hispano-hablantes 
da América e também nos países da Pensínsula Ibérica (Portugal e Espanha), desenvolve-se dentro deste quadro geral narrativas cujos narradores, refletindo os problemas, questionamentos e preocupações dos próprios autores, centram-se em dois focos principais que podem se ver fundidos num só. Conforme podemos notar num diálogo entre personagens, no conto "Na data Magna de nosso calendário cívico", de Luís Fernando Emediato. A personagem Lúcia, que tem a postura de uma militante aguerrida, disposta a enfrentar o regime, afirma que não consegue "entender como é possível a um artista voltarse para dentro de si mesmo enquanto, ao seu redor, a massa faminta uiva marginalizada e reprimida!" (1994, p. 133). A resposta do personagem Afonso, um estudante e pretenso escritor/romancista, reforça a percepção desta problemática dos artistas da época em geral e do escritor em particular. Ele "não faria esse tipo de arte alienada" afirma Afonso e prossegue: "Eu preparo a minha crítica ao Sistema, mas não posso externá-la agora em virtude da proximidade histórica [...] Se a ditadura cair, eu deixo a poeira assentar e escrevo meu romance. Se não cair, eu posso deixar o país e observar as coisas de fora" (p. 132, 133). Assim, o desejo de escrever um romance, ou de produzir arte de um modo geral, apresenta-se como uma problemática não apenas estética mas sobretudo ética.

Muitos romances da literatura brasileira recente que versam sobre a ditadura militar fazem périplos na busca pelo trabalho de romancear, de escrever romances, muito embora isto não seja algo abolutamente novo, conforme afirmamos num texto apresentado na ABRALIC, a citação é longa mas necessária: "Este auto-espelhamento narrativo tem se apresentado de modos muitos diversos e não à toa existem teorias que tentam dar conta do mesmo, como o belíssimo trabalho de Linda Hutcheon sobre narrativa narcísica, tipo de romance em que ocorre uma reflexão sobre o processo de escritura, uma auto-consciência formal e temática, além de frequentes auto-espelhamentos, não-raro pelo uso do mise-enâbime. Em muitos casos, o leitor está diante do romance que se vai escrevendo conforme o 
avanço da leitura. Em Machado, até mesmo reflexões tipográficas sobre o formato da folha em que será vasado o livro a ser metido no prelo estão espargidos em quase todos os romances. Entretanto, temos casos notáveis de publicações de livros/romances cujo relato se refere à busca por um romance não escrito" (PACHECO, 2014, p. 05) ou de um romance perdido, a exemplo do romance de Renato Pompeu.

Quatro-Olhos, publicado pela primeira vez em 1976, traz na contra-capa a afirmação de não se tratar de "um livro de memórias". Por si, uma armadilha. Ao citar o gênero memorialístico, a advertência em um lugar de destaque comercial e onde normalmente vão os leitores em busca de informações ${ }^{3}$, parece reforçar um direcionamento de leitura mesmo pela negação. Durante a leitura, não se deixará de julgar como o romance, pelo menos como uma biografia de personagens ficcionais - como de fato pode ser lido. O enredo principal refere-se a uma obra prima, um romance absolutamente original que o narrador teria escrito dos dezesseis aos vinte e nove anos "no mínimo, três a quatro horas todos os dias" - como se afirma no parágrafo inicial - mas que fora perdido. Sobre a perda do livro, o parágrafo inicial afirma que ocorreu "há muitos anos, em circunstâncias que não me convém deixar esclarecidas" (1976, p. 15). Entretanto, no penúltimo episódio o narrador afirma que os policias entraram em sua casa e "foram apanhando os livros. Numa gaveta do escritório, encontraram meu manuscrito. Nunca mais o vi. Meses depois, eu estava internado no hospital psiquiátrico, onde resolveram me chamar de Quatro-Olhos" (p. 136). Apenas neste momento sabemos, mesmo que sem certeza alguma que a narrativa foi escrita durante a internação.

Segundo Lizandro Calegari, este romance assenta-se "numa construção literária pautada na fragmentação, no uso de uma linguagem de caráter anti-realista, no

\footnotetext{
${ }^{3}$ Em geral, a informação sobre a não veracidade dos fatos fica na página de créditos da edição, como ainda faz a Cia das Letras em quase todos os seus romances. 
questionamento da narrativa e na luta contra o esquecimento" (2008, p. 246) podendo ser classificada como "literatura do trauma" conforme a leitura que faz do texto do prof. Márcio Seligmannn-Silva, publicado na revista Cult número 23. Quatro-Olhos é inscrito no campo da auto-reflexividade ou auto-espelhamento narrativo predominantemente no campo da incerteza. Ao tentar resgatar o romance perdido, o narrador preso em sua interioridade exila-se da sociedade circundante. Procedimento comum em autobiografias conforme afirma Lejeune (1996). O narrador-autor-protagonista vive apenas o passado que deseja resgatar, todo o presente histórico é anulado. O autobiógrafo permanece preso ao passado que narra. Ele vive este passado, em geral, refletindo sobre situações e fatos apenas do passado. Todo o presente é nulo. Igualmente percebemos isto nas autobiografias de personagens de ficção, mesmo nos casos em que esses romances demarcam de maneira clara a topografia da narração, como nos exemplos citados de Machado de Assis, Guimarães Rosa e Milton Hatoum.

Em Quatro-Olhos, mesmo pela negação, este presente do momento da escrita penetra na narração. É assim, por exemplo, que a referência à tortura é narrada. Greves e outras também. Afinal, o narrador tem um desejo de efetuar um "ataque ao presente" (p. 28). Este ataque se consolida não só triscando as bordas do furacão, mas (de modo mais significativo) através do próprio processo de destruição do romance, não só pela narração da forma como o romance se dilacerou tendo virado papel de embrulhar pão, folhas espalhadas em transporte público em São Paulo, mas também pela própria imagem do romance. As incertas, as fragmentações, as descontinuidades narrativas ajudam a espectrar a mixórdia que é a narrativa.

Auxilia no processo a ausência de um cenário específico para a narração. Embora haja uma referência vaga ao hospício, ela se desenvolve fora de qualquer referência topográfica explícita. Esta cena, se conforma diluída numa autarquia ou autonomia 
semântica. A crítica à realidade histórica circundante ganha força por esta supra espacialidade, inscrita também num contexto de contestação à hora, mas testemunho (ela mesma testis e supertis, tanto terceira como vítima cujo corpo dilacerado se mostra) na cena ou supra-cena do tribunal da História.

\section{Referências:}

ADORNO, Theodor W. Posição do Narrador no Romance Contemporâneo. In: Notas de literatura I. Trad.: Jorge de Almeida. São Paulo: Duas Cidades/ Editora 34, 2003. p. 55-63.

BENJAMIN, Walter. Experiência e Pobreza. . In: Obras escolhidas. Trad.: Sérgio Paulo Roaunet. São Paulo: Brasiliense, 1994. p. 114-119.

BENJAMIN, Walter. O Narrador: considerações sobre a obra de Nikolai Leskov. In: Obras escolhidas. Trad.: Sérgio Paulo Roaunet. São Paulo: Brasiliense, 1994.

BOSI, Alfredo. Narrativa e Resistência. In: . Literatura e resistência. São Paulo:

Companhia das Letras, 2002. p. 118-135.

CALEGARI, Lizandro Carlos. A literatura contra o autoristarismo: a desordem social como princípio da fragmentação na ficção Brasileira pós-64.

CALVINO, Italo. As cidades invisíveis. Tradução Diogo Mainardi. São Paulo: Companhia das Letras, 1990.

EMEDIATO, Luis Fernando. Verdes Anos. 2. ed. rev. pelo autor. São Paulo: Geração Editorial,. 1994.

GAGNEBIN, Jean M. Lembrar, Escrever, Esquecer. São Paulo: Ed. 34, 2006.

HUTCHEON, LINDA. Narcissistic Narrative: The Metafictional Paradox. Waterloo, ON: Wilfrid Laurier UP, 1980.

LEJEUNE, Philippe. El pacto autobiografico y otros estudios. Traducción de Ana Torrent. Madrid: Megazul, 1996.

MAINGUENEAU, Dominique. Novas Tendências em Análise do Discurso. 
MAINGUENEAU, Dominique. Discurso Literário.

PACHECO, Abilio. Contra-contos em (des)encontro: a demanda pelo protagonista como resistência e construção de si em "A terceira margem" de Benedicto Monteiro. In: Anais do XIV Encontro da ABRALIC, Belém, 2014.

POMPEU, Renato. Quatro-olhos. São Paulo: Ed. Alfa-omega, 1976.

SELIGMANN-SILVA, Márcio, Literatura e trauma: um novo paradigma. In: $O$ local da diferença. Ensaios sobre memória, arte, literatura e tradução. São Paulo: Editora 34, 2005a. 63-80.

SELIGMANN-SILVA, Márcio. História, memória e literatura. Campinas: Unicamp, 2003.

SELIGMANN-SILVA, Márcio. Grande Sertão: Veredas como gesto testemunhal e confessional. Alea, Rio de Janeiro, v. 11, n. 1, p. 130-147, June 2009. 